\title{
Binding Affinities Studies of Nitrated Model Peptides to Monoclonal Anti-3-nitrotyrosine Antibody
}

\author{
LAURA ION ${ }^{1}$, ANCUTA-VERONICA LUPAESCU ${ }^{1}$, ANDREI NEAMTU ${ }^{2,3}$, GABI DROCHIOIU ${ }^{1}$, \\ BRINDUSA-ALINA PETRE ${ }^{1,2 *}$ \\ ${ }^{1}$ Alexandru Ioan Cuza University, Department of Chemistry, 11 Carol I Blvd., 700506 Iasi, Romania \\ ${ }^{2}$ Regional Institute of Oncology, Center for Fundamental Research and Experimental Development in Translation \\ Medicine, 2-4 General Henri Mathias Berthelot Str., 700483 Iasi, Romania \\ ${ }^{3}$ Gr. T. Popa University of Medicine and Pharmacy of Iasi, Department of Physiology, 16 Universitatii Str., Iasi, \\ Romania
}

\begin{abstract}
Tyrosine nitration has been shown to be an important oxidative protein modification and play a crucial role in pathophysiological conditions, associated with oxidative stress, such as atherosclerosis and neurodegenerative disease. For a better understanding of nitration mechanism, the identification and the quantification of nitration sites represents an important research goal. Due to (i) the low levels of nitration in native proteins, (ii) structural changes induced by nitration and (iii) the specificity of anti - 3 nitro tyrosine antibodies the method which may provide the identification of nitration sites in proteins represent a challenging experimental task. In this work we have used synthetic nitrated tyrosine containing peptides to determine antibody-binding affinities and specificity of different tyrosine residue $\left(T_{y} r^{33}, T y r^{98}, T^{2} r^{107}\right.$ and $T y r^{122}$ ) in Eosinophil cationic proteins (ECP). The highest affinity of nitrated ECP peptides to the monoclonal antibody (anti-3NT) was obtained for the only in vivo nitrated identified residue $\operatorname{Tyr}^{33}(0.082 \mu \mathrm{M})$; in contrast, all other three nitrated residues at Tyr ${ }^{98}$, Tyr $^{107}$ and Tyr $^{122}$ ) showed significant lower affinity being imbedded in the ECP protein structure as similar resulted by molecular computational modeling.
\end{abstract}

Keywords: proteintyrosine nitration, nitro-tyrosine antibodies, ELISA, circular dichroism spectroscopy

Eosinophil granules are a type of white blood cells and play an important rol in allergic inflammation and tissue homeostasis of hypersensitive diseases [1-3]. Eosinophil granules include four types of proteins: major basic protein (MBP-1, MBP-2), eosinophil peroxidase (EPO), eosinophil cationic protein (ECP), and eosinophil - derived neurotoxin $(\mathrm{EDN})$ that received considerable attention over the past two decades $[4,5]$. Eosinophil cationic protein (ECP) is one of the four cationic proteins from human eosinophil granules involved in the immune system, having the ability to generate oxidizing species. The ECP polypeptide is a basic protein (due to a high number of arginine residue) having 133 amino acids from which only four tyrosine residue considered possible sites for nitration [6, 7].

Nitration of tyrosine represents an oxidative post-translation modification in proteins which normally may occurs in physiological conditions and plays an important role in several pathophysiological conditions such as asthma [8], atherosclerosis [9], diabetes [10] and in neurodegenerative disease such as Alzheimer and Parkinson diseases [11-13], all associated with oxidative cellular stress. Tyrosine nitration or nitro-tyrosine (3-NT) alters first the protein structure and function, affects biological half-life, and may also hinder the phosphorylation of key tyrosine residues involved in signal transduction pathways of important protein biomarkers [14]. The investigated in vivo mechanisms that introduces nitro group in ortho - position of tyrosine side chain residue in proteins are based on (i) peroxynitrite formation in the cell [15] and the activity of myeloperoxidase (MPO) and eosinophil - peroxidase (EPO) in presence of oxidative scavengers [16]. 3-Nitro tyrosine modification in proteins and peptides presents special challenges due to low levels of modification present in vivo under endogenous condition and artifactual formation in in vitro studies and not only [17]. For the characterization and identification of tyrosine nitration, mostly immuno-analytical methods such as ELISA, Western blot and immuno-staining have been used in the literature [18-19]. These methods are based on using commercial antibodies against 3-nitrotyrosine (3-NT) and provide only information about nitration levels, with no information about structure or about identification of nitration sites [20]. Therefore the identification and structural characterization of nitro-tyrosine sites in proteins becomes a difficult task for mass spectrometry, the most common method used currently in proteomics to determine molecular masses of peptides, proteins and their modification [21, 22]. However, major problems in using MS methods for identification and quantification of nitration in proteins may appear due to the low levels of nitration in biological samples and instability and decomposition of nitrated peptides under MS conditions in case of using MALDI (matrix-assisted laser desorption/ionization) mode [23, 24].

*email: brindusa.petre@uaic.ro 
In recent studies, new proteolytic affinity extraction method combined with mass spectrometry/combined affinitymass spectrometry methods have been successfully developed for molecular identification and structural characterization of epitopes in protein modifications [25-27]. Using this combination of proteolytic affinity extraction and mass spectrometry, structural characterization and nitration sites have been in vivo identified in eosinophil granule proteins [22]. Isolated or synthetic model peptides were used in many studies and are considered as potent biomolecules with diverse biomedical implication in several pathologies [28, 29].

Based on previous researches, considerable differences were noticed in binding affinities of tyrosine nitration peptides to anti-3NT-antibodies, which led to a specific epitope motif to 3NT-antibodies recognition [25]. Due to this specific results obtained by the identification of the endogenous nitration site in eosinophil cationic proteins [22], four nitrated model peptides were synthesized by SPPS using Fmoc / t-Butyl strategy. Here, we present the structural characterization and binding affinities and specificities of all four nitrated ECP peptides to a monoclonal anti-3NTantibody that were investigated by circular dichroism (CD) spectroscopy [30, 31]and indirect enzyme-linked immunosorbent assay (ELISA) [32, 33] respectively. The experimental results indicate different selectivity for all four eosinophil nitrated model peptides to a specific anti 3-nitrotyrosine antibody and only the peptide containing the in vivo nitro tyrosine modification exhibit high binding response in ELISA experiments. CD spectroscopy showed a decrees of the degrees of ellipticity for the three model nitrated ECP peptides that were not found as being nitrated in the native protein. Computational modeling studies indicate that in vivo nitration is a high selective modification of proteins and critically depends on the structural protein conformation, solvent accessibility, proximity and reactivity of reactive oxygen / nitrogen species. Moreover, immune-affinity bindings of 3-nitro-tyrosine antibodies to nitrated tyrosine containing peptides rely on amino acids surrounded by 3-nitrotyrosine site.

\section{Experimental part}

Materials and methods

Mouse monoclonal anti-3-nitrotyrosine antibody (MAB5404) was purchase from Chemicon International (Bubendorf, Switzerland). N- $\alpha$-Fmoc protected amino acids, NovaSyn TGR resin, $\mathrm{N}-\alpha$-Fmoc protected amino acids attached to NovaSyn TGA resin, benzotriazol-1-yl-oxytripyrrolidinophosphonium hexafluorophosphate (PyBOP), activator used for peptide synthesis, were obtained from NovaBiochem (Laufelfingen, Switzerland). The N- $\alpha$-Fmoc-3nitrotyrosine amino acid was purchase from Bachem (Bubendorf, Switzerland). The plates were activated using disuccinimidyl suberate solution (DSS) purchase from Sigma Aldrich, Germany. Disodium hydrogen phosphate-2hydrate $\left(\mathrm{Na}_{2} \mathrm{HPO}_{4}\right)$, o-phenylenediamine dihidrochoride (OPD), 30\% hydrogen peroxide, polyoxyethylensorbitanmonolaureat (Tween 20), acid trifloroacetic (TFA) and acetonitrile (ACN) were purchase from Sigma Aldrich, Germany. Horse radish peroxidase (HPR) goat anti-mouse IgG antibody was obtained from Jackson Immunoresearch, USA.

\section{Solid phase peptide synthesis and High-performance liquid chromatography of nitrated ECP peptides}

The nitrated peptide sequences were synthesized using an automated peptide synthesizer EPS 221 (Intavis, Langenfeld, Germany) by Solid phase peptide synthesis and Fmoc/tBu strategy protection chemistry. Peptides were synthesized on a TGA resin, coupling reactions were performed for $30 \mathrm{~min}$ at room temperature and $5 \mathrm{~min}$ deprotection using 20\% piperidine in dimethylformamide (DMF).The final cleavage and deprotection of peptide from the resin was performed in presence of TFA as cleavage reagent, trietylsilan and ionized water as scavengers in a ration of 95: 2.5: 2.5 for 2-3 hours at room temperature in dark conditions. After cleavage, the crude peptides were precipitated with $50 \mathrm{~mL}$ cold TBME (t-buthylmethylether) over night at $-20^{\circ} \mathrm{C}$. The peptide and the resin were separated by filtration and solubilized in 5\% acetic acid (aqueous solution) prior to freeze with liquid nitrogen and lyophilized. For peptides purification analytical RP-HPLC using a Bio-Rad system (Bio-Rad Laboratories, Richmond, CA) was performed. Separation was carried out on a Polymer-PLRP $(250 \times 4.6 \mathrm{~mm}, 300 \AA, 5 \mu \mathrm{m})$ (Polymer Laboratories, Darmstadt, Germany) at a flow rate of $1 \mathrm{~mL} / \mathrm{min}$, using a gradient elution system of $0.1 \%$ TFA as solvent A and 0.1\% TFA in acetonitrile: water, 80:20 (v: v) as solvent B, 10-60\% in 55 min. Detection of nitrated peptides was monitored at a specific wavelength of $365 \mathrm{~nm}$. For preparative purification was used a Knauer system (Bad Homburg, Germany) using a preparative $\mathrm{C}_{18}$ column (Grom-Sil 120 ODS-4 HE, $10 \mu \mathrm{m}, 250 \times 20 \mathrm{~mm}$, (Grom, Herrenberg, Germany) at a flow rate of $10 \mathrm{~mL} / \mathrm{min}$; the eluent conditions were identical as those for analytical RPHPLC.

\section{Enzyme Linked Immunosorbent Assay (ELISA)}

ELISA experiment was performed using 96-well CovaLink-NH plates (Nunc GmbH \& Co. KG, Wiesbaden, Germany) which were activated for 1 hour at room temperature with $150 \mu \mathrm{L} /$ well disuccinimidyl suberate (DSS) solution. After incubation over night at room temperature with $150 \mu \mathrm{L} /$ well of peptides solutions, using 8 serial dilutions of in a concentration range $0.003-3 \mu \mathrm{M}$ prepare in PBS buffer $\left(5 \mathrm{mM} \mathrm{Na}_{2} \mathrm{HPO}_{4}, 150 \mathrm{mM} \mathrm{NaCl}, p \mathrm{H}=7.5\right)$, the plate was washed four times with $0.05 \%$ Tween-20 in PBS, $p \mathrm{H}=7.5$ and then blocked with 5\% BSA in PBS 
buffer for 2 hours at room temperature. After adding the anti 3-nitrotyrosine, $150 \mu \mathrm{L} /$ well antibody : 5\% BSA (1 : 2500 ratio), the plate was incubated for one hour at room temperature and washed several times. $150 \mu \mathrm{L}$ of peroxidase labeled goat anti-mouse IgG diluted 10000 times in 5\% BSA was added and after one hour incubation time and washing with two different washing buffer, with PBS-T (three times) and with $0.05 \mathrm{M}$ sodium phosphate-citrate buffer, $p \mathrm{H}=5$, o-phenylenediamine (OPD) dihydrochloride in sodium phosphate-citrate buffer, $p \mathrm{H}=5(\mathrm{c}=1 \mathrm{mg} / \mathrm{mL})$ and $30 \%$ hydrogen peroxide (two times) respectively, the plate was incubated for 10 minutes at RT. The absorbance was measured on a Wallac 1420 Victor $^{2}$ ELISA Plate Counter (PerkinElmer, Boston, MA) at $450 \mathrm{~nm}$. The ELISA protocol was optimized during few previous experiments in terms of peptide concentration and antibodies dilutions to diminish false positive responses and background effect.

\section{Circular Dichroism Spectroscopy}

Circular dichroism (CD) spectra were recorded on a Jasco spectropolarimeter, J-715 model, equipped with Xe lamp. The measurements were carried out in water and in trifluoroethanol (which stabilize peptide and proteins in ordered conformation) at $25^{\circ} \mathrm{C}$ using a quartz cell of $0.05 \mathrm{~cm}$ path-length. For instrument calibration $0.07 \%(\mathrm{w} / \mathrm{v}$ ) ammonium-d-camphor-10-sulfonate in tri-distilled water was used. Results, average of five scans, were expressed in terms of molar ellipticity $\left(\mathrm{deg} \cdot \mathrm{cm}^{2} \cdot \mathrm{dmol}^{-1}\right)$ after solvent baseline subtraction.

\section{Computational details}

All the calculations were performed on models derived from the eosinophil cationic protein crystal structure with the code 1H1H in the Protein Data Bank [34]. Solvent accessible surface area (SASA) of the tyrosine residues were calculated from the crystallographic structure using the method of Eisenhaber et al. [35] was used, as implemented in 'gmx sasa' program of GROMACS 5 suite [36]. The program first computes the solvent accessible surface of the entire protein and then extracts the area of the patches corresponding to each residue. Molecular dynamics simulations were performed with the Desmond program as implemented in Schrödinger Maestro Suite 2019/2 [37, 38]. The OPLS_2015 [39] force field was used for the protein and TIP3P [40] model for the water molecules. The protein model was solvated in a cubic box containing a physiological solution of $150 \mathrm{mM} \mathrm{NaCl}$ in water. The system was energy minimized and then relaxed using several short simulations with the heavy atoms of the protein constrained to their initial positions. This allowed for the solvent to adapt to the protein surface. Finally, a 10 ns production run was performed at constant pressure $(1 \mathrm{~atm})$ and temperature $(300 \mathrm{~K})$. Long-range electrostatic interactions were evaluated using Particle Mesh Ewald (PME) summation [41]. Desmond trajectory was converted to GROMACS 5 format for analysis, using the InterMol program [42]. Radial distribution functions of atoms positions and inter-atomic contacts were calculated using 'gmx rdf' and 'gmx mindist' tools in GROMACS 5 suite.

\section{Results and discussions}

Synthesis and Structural Characterization of Tyrosine-nitrated Peptides of Eosinophil Cationic Protein

Nitrated model peptides containing all four tyrosine residue in eosinophil cationic protein primary sequence (Tyr ${ }^{33}$, $\mathrm{Tyr}^{98}, \mathrm{Tyr}^{107}, \mathrm{Tyr}^{122}$ ), were synthesized by SPPS using Fmoc protection chemistry (peptide noted 1- 4 in Table 1). The crude peptides were purified by HPLC and characterized by MALDI-ToF mass spectrometry. The analytical HPLC characteristics and molecular ions masses of synthetic nitrotyrosine ECP peptides determined by mass spectrometry are summarized in Table 1.

Tabel 1

RP-HPLC and MALDI-ToF-MS DATA of SYNTHETIC ECP PEPTIDES

\begin{tabular}{|c|c|c|c|c|c|}
\hline $\begin{array}{l}\text { Peptide } \\
\text { No. }\end{array}$ & Code & Sequence & $\begin{array}{l}\text { Nitration } \\
\text { site }\end{array}$ & $\begin{array}{c}\text { HPLC } \\
\text { Rt }_{\mathbf{t}}(\min )^{\mathbf{a}}\end{array}$ & $\begin{array}{c}{[\mathrm{M}+\mathrm{H}]^{+}} \\
\text {calculated / found }^{\mathrm{b}}\end{array}$ \\
\hline$\underline{\mathbf{1}}$ & $\mathrm{ECP}_{1}$ & ${ }^{28}$ AINNYRWRCL ${ }^{38}$ & Nitro-Y ${ }^{33}$ & 17.58 & 1367.65 / 1368.81 \\
\hline$\underline{2}$ & $\mathrm{ECP}_{2}$ & ${ }^{92}$ NISNCRYADR ${ }^{101}$ & Nitro-Y ${ }^{98}$ & 15.57 & $1255.53 / 1256.75$ \\
\hline$\underline{\mathbf{3}}$ & $\mathrm{ECP}_{3}$ & ${ }^{101}$ RPGRRFYVVA ${ }^{110}$ & Nitro-Y $Y^{107}$ & 18.07 & $1265.68 / 1266.57$ \\
\hline$\underline{4}$ & $\mathrm{ECP}_{4}$ & ${ }^{118}$ DSPRYPVVPVHL ${ }^{129}$ & Nitro-Y $Y^{122}$ & 14.25 & $1423.73 / 1424.61$ \\
\hline
\end{tabular}

\section{Binding affinities of nitrated tyrosine-nitrated eosinophil peptides}

In order to identify the specific sequence for tyrosine-nitrated ECP peptides which strongly bind to an anti-3NT antibody, affinity binding experiments were performed using indirect ELISA immuno-method. After addition of 3-NT antibody on the 3-nitrotyrosine ECP peptides immobilized on CovaLink plates [43], a second peroxidase conjugated 
antibody and $\mathrm{OPD} / \mathrm{H}_{2} \mathrm{O}_{2}$ substrate was added. The absorbance was measured at $450 \mathrm{~nm}$ using a Wallac 1420 Victor $^{2}$ ELISA plate counter (Section in Material and Methods). To measure the affinities of ECP nitrated model peptide to the selected monoclonal antibody the maximum reaction was consider for all peptides as $100 \%$ and then the concentration required to obtain an half maximum binding $\left(\mathrm{OD}_{450}=50 \%\right)$ were analyzed. ELISA data presented in figure 1 shows that $\mathrm{ECP}_{1}$ peptide, containing $\mathrm{Tyr}^{33}$ has the highest affinity to the monoclonal 3-NT antibody compared with the other nitro tyrosine ECP-peptides. This fact suggests that the primary amino acid sequence surrounding the nitrated tyrosine residue is directly responsible for the affinity differences between these model peptides.

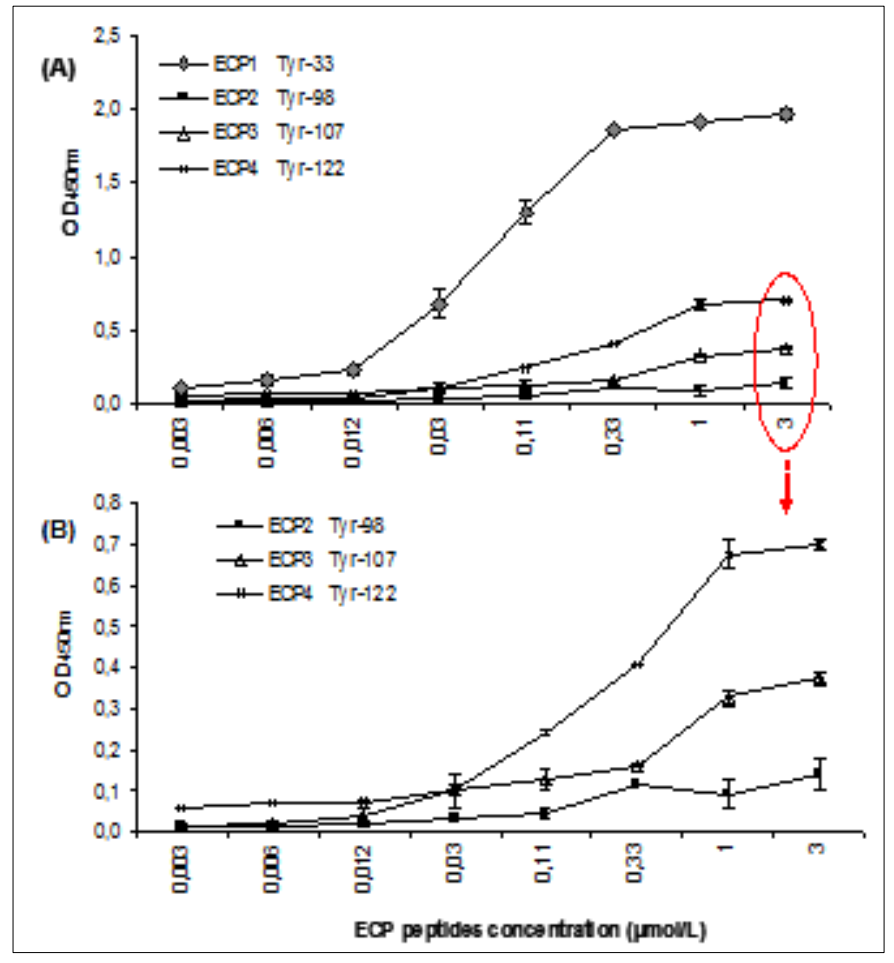

Fig 1. Binding of monoclonal anti 3NT antibody to the tyrosine nitrated ECP peptides measured by indirect ELISA. The background signal resulted by undesired direct absorbance of the antibody on CovaLink plates without peptides antigen solutions have been subtracted

As shown in figure $1 \mathrm{~A}$, the highest intensity of nitrated $\mathrm{ECP}_{1}$ binding to the monoclonal anti 3-NT antibody was obtained for $0.082 \mu \mathrm{M}$ (lowest quantity of peptide to obtain an $\mathrm{OD}_{450}$ of 50\%). In figure 1B the region with maximum binding for other three nitrated ECP peptides is represented. Nitrated $\mathrm{ECP}_{4}$ and $\mathrm{ECP}_{3}$ peptides have the highest binding affinity to the monoclonal anti-3NT antibody at a concentration of $0.31 \mu \mathrm{M}$ and $0.85 \mu \mathrm{M}$ respectively, although nitrated $\mathrm{ECP}_{2}$ peptide (where Tyr-98 in the protein structure is almost hided) has no notable interactions with the antibody. By these findings, the premise that the anti 3-NT antibody identify an epitope motif consists of several amino acids in the region of the nitro-tyrosine residue was confirmed.

Conformational characterization of nitrated ECP peptides by Circular Dichroism spectroscopy. For experimental conformational characterization of the synthetic ECP nitrated peptides circular dichroism spectroscopy was used. As seen in figure 2, the measurements were carried out in presence of tri-distilled water (MilliQ) and trifluoroethanol (TFE). TFE is considered in the literature as a solvent that stabilize usually peptide and proteins in ordered conformations. The CD spectra of tyrosine nitrated ECP peptides in water present a negative band lower than $200 \mathrm{~nm}$ and a minor positive band at around $220-225 \mathrm{~nm}$ which indicate a random coil conformation (Fig. 2A). From all nitrated peptides solubilized in water and measured by $\mathrm{CD}$ spectroscopy, $\mathrm{ECP}_{1}$ with $\mathrm{Tyr}^{33}$ presented the lowest ellipticity. On the other hand, in TFE, the nitrated ECP peptides adopt different conformations (Fig. 2B). The Tyr ${ }^{33}$ nitrated peptide $\left(\mathrm{ECP}_{1}\right)$ has the most ordered conformation with an intensive positive band at $188 \mathrm{~nm}$ and a large negative band at around $208 \mathrm{~nm}$. Meanwhile, peptides $\mathrm{ECP}_{2}$ and $\mathrm{ECP}_{3}$ adopt an ordered structure, having the positive band $\left(\pi-\pi^{*}\right.$ perpendicular transition) moved to $\sim 186 \mathrm{~nm}$, the first negative band ( $\pi-\pi^{*}$ parallel transition) shifted around $204 \mathrm{~nm}$ and the second negative band ( $\mathrm{n}-\pi^{*}$ transition) shifted at $\sim 228 \mathrm{~nm}$, structure which is close to the theoretical helix shape. Only the nitrated peptide $\mathrm{ECP}_{4}$ in the presence of TFE shows no notable conformational changes; it adopts a random coil conformation either in water or TFE demonstrating that trifluoroethanol does not arbitrarily favor helix conformation, it only strengthen the existing structural tendency. 


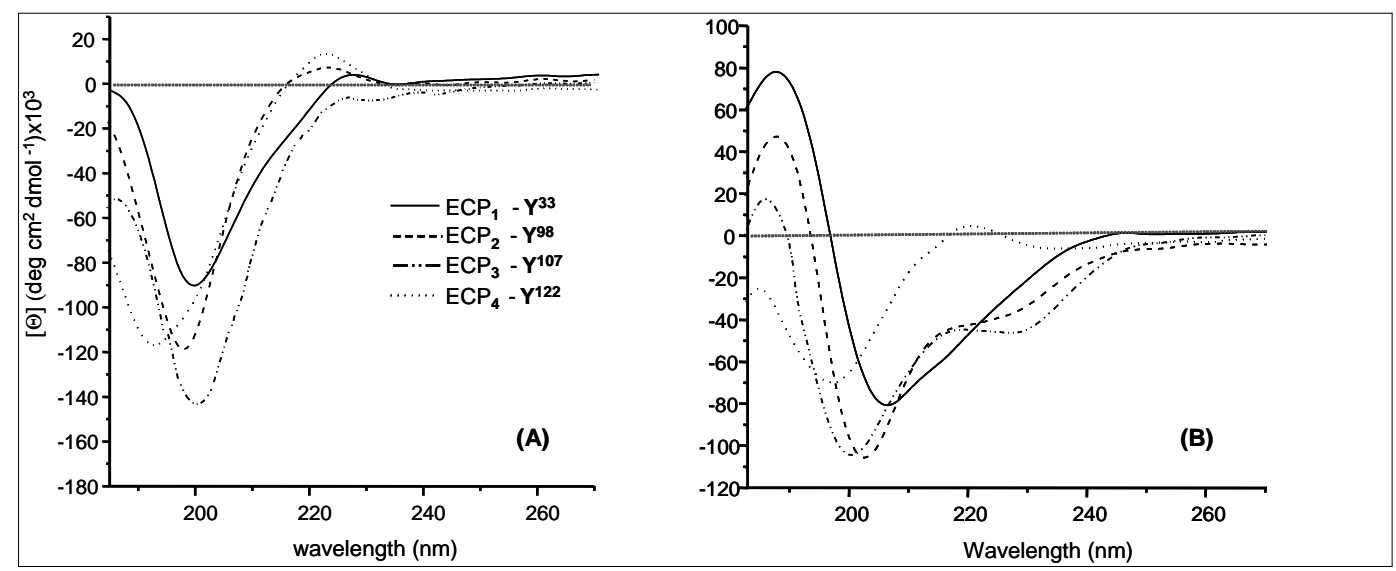

Fig 2. CD spectra of (A) nitrotyrosine ECP model peptides in MilliQ and (B) trifluoroethanol (100\%)

These results suggest that the important factors which manage the selectivity of in vivo nitrated proteins are the primary amino acids sequence and its conformation. $\mathrm{The}^{\mathrm{Tyr}^{33}}$ (i) is placed in a flexible turn inducing sequence (Fig. 3) and (ii) no other amino acids susceptible for oxidation such as histidine, cysteine or methionine are in its close proximity (peptide sequence in Table 1). This residue $\left(\mathrm{Tyr}^{33}\right)$ can represents an alternative targets for reactive nitrogen species (RNS) reaction, so those two major factors stimulate specific nitration of $\mathrm{Tyr}^{33}$ in eosinophil cationic protein.

Computational modeling of Eosinophil Cationic Protein and nitrated ECP peptides. The crystallographic threedimensional model of eosinophil cationic protein $(\mathrm{ECP})(\mathrm{PDB} 1 \mathrm{H} 1 \mathrm{H})$ was used to measure the solvent accessible surface area (SASA) of $\mathrm{Tyr}^{33}, \mathrm{Tyr}^{98}, \mathrm{Tyr}^{107}$ and $\mathrm{Tyr}^{122}$ residues. Tyrosine in position 33 showed the largest SASA of $0.846 \mathrm{~nm}^{2}$. In comparison, Tyr ${ }^{98}, \mathrm{Tyr}^{107}$ and $\mathrm{Tyr}^{122}$ had SASA of $0.067 \mathrm{~nm}^{2}, 0.060 \mathrm{~nm}^{2}$ and $0.711 \mathrm{~nm}^{2}$ respectively. These values suggest that $\mathrm{Tyr}^{98}$ and $\mathrm{Tyr}^{107}$ are buried under the protein surface, while $\mathrm{Tyr}^{33}$ and $\mathrm{Tyr}^{122}$ are exposed towards the solvent environment, as it can also be seen from the visual representation of the ECP structure (Fig. 3). However, considering that proteins are flexible structures, calculating structural properties only for a singular macromolecular conformation may lead to inaccurate results. This is especially true for X-ray determined structures that constrain the protein molecules in a non-physiological environment. Thus, an ensemble of conformations was generated by conducting explicit solvent molecular dynamics (MD) simulations on the ECP model. The number of close contacts (inter-nuclear distance $<0.3 \mathrm{~nm}$ ) between the side chain atoms of each of the four tyrosine residues with the water molecules " $\mathrm{N}$ " were calculated during the MD simulation. The $\mathrm{Tyr}^{33}$ residue showed an average $\mathrm{N}=$ 6.85 which is close to the $\mathrm{N}=5.54$ for the $\mathrm{Tyr}^{122}$ residue. These two residues displayed the largest number of solvent contacts, in line with the SASA measurements on the static crystallographic structure. The exposure towards the solvent environment reflects a higher propensity of these residues for a possible post-translational modification. The $\mathrm{Tyr}^{98}$ residue had an average $\mathrm{N}=0.036$ reflecting a highly reduced solvent exposure. However, $\mathrm{Tyr}^{107}$ that had a SASA comparable to $\mathrm{Tyr}^{98}$ in the crystal structure, provided a highly increased number of solvent contacts $(\mathrm{N}=1.52)$ in the MD simulations, which highlights the importance of protein flexibility and dynamics in solvent exposure of near-surface buried residues. To further sustain these findings, we calculated the radial distribution functions (RDF) of the oxygen atom of water molecules around the hydroxyl oxygen atom of each of the four tyrosine residues. The plots in figure 4 were not normalized for volume and density. Therefore, the area under each curve is proportional to the number of water molecules around the hydroxyl of the corresponding tyrosine residue. The side chain of Tyr ${ }^{33}$ had the most numerous interactions with the solvent, slightly higher than $\mathrm{Tyr}^{122}$, and more numerous than $\mathrm{Tyr}^{107} \mathrm{and} \mathrm{Tyr}^{98}$. The absence of the first maximum in the RDF of $\mathrm{Tyr}^{98}$ showed that its side chain had a stable buried conformation, the hydroxyl group making no contacts with the surrounding solvent.

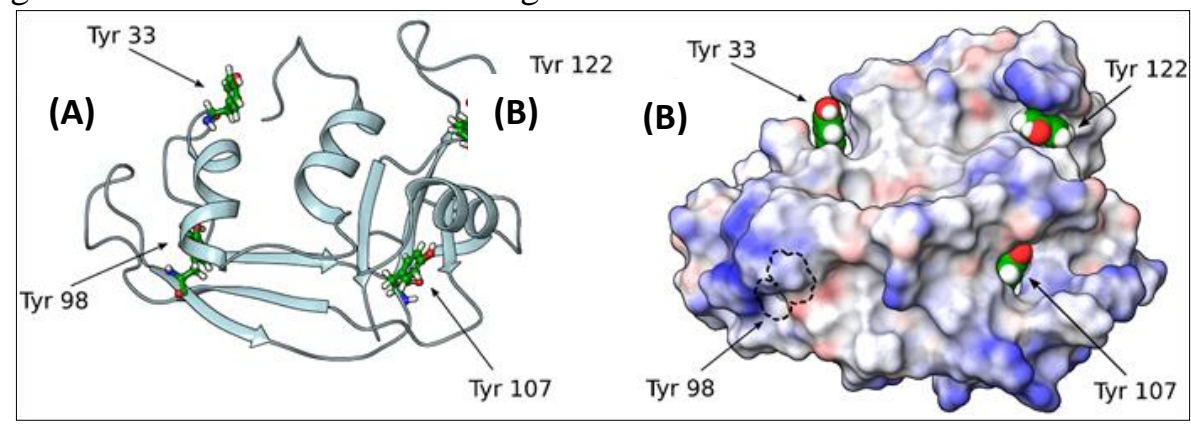

Fig 3. The location and the surface exposure of the four tyrosine residues of the human eosinophil cationic protein (ECP). (A) Ribbon diagram of the X-Ray crystal structure (PDB accession number $1 \mathrm{H} 1 \mathrm{H})$.

(B) Surface representation (A) of ECP colored by the electrostatic potential. The $\mathrm{Tyr}^{33}, \mathrm{Tyr}^{107}$ and $\mathrm{Tyr}^{122}$

side chains were represented as spheres. The $\mathrm{Tyr}^{98}$ side chain is completely buried under the protein surface 


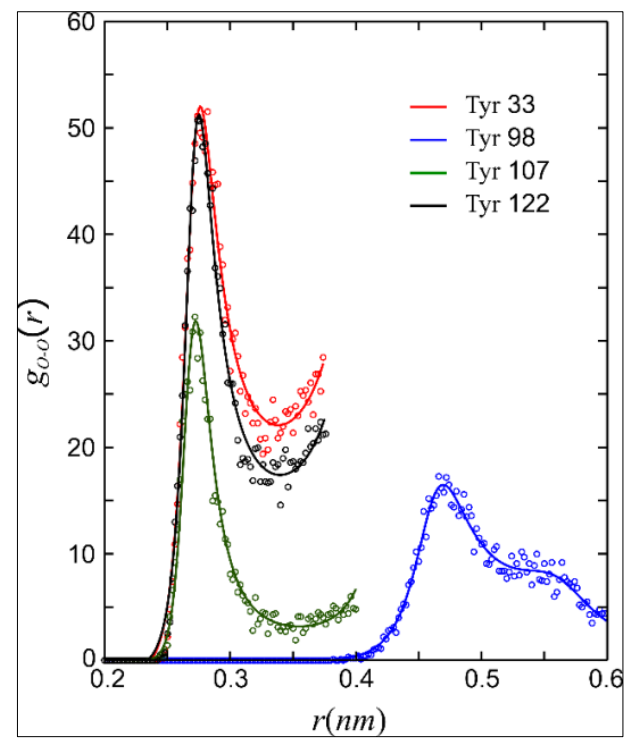

Fig 4. The radial distribution functions of the oxygen atom of water molecules around the hydroxyl oxygen atom of the tyrosine residues

Molecular dynamic simulation with HyperChem 6.0 software was used for structural characterization of the new synthetic nitrated peptides. For geometry optimizations were applied AMBER96 parameters and calculations were performed taking into consideration water molecules. From structural modeling calculations we observed that the $\mathrm{ECP}_{2}$ and $\mathrm{ECP}_{4}$ structure are more flexible by having an open structure compared with $\mathrm{ECP}_{1}$ and $\mathrm{ECP}_{3}$ which are more compact (Fig. 5) and explain both, the results of different binding affinities of nitrated ECP peptides to monoclonal anti 3-nitro-tyrosine antibody and CD spectroscopy data.

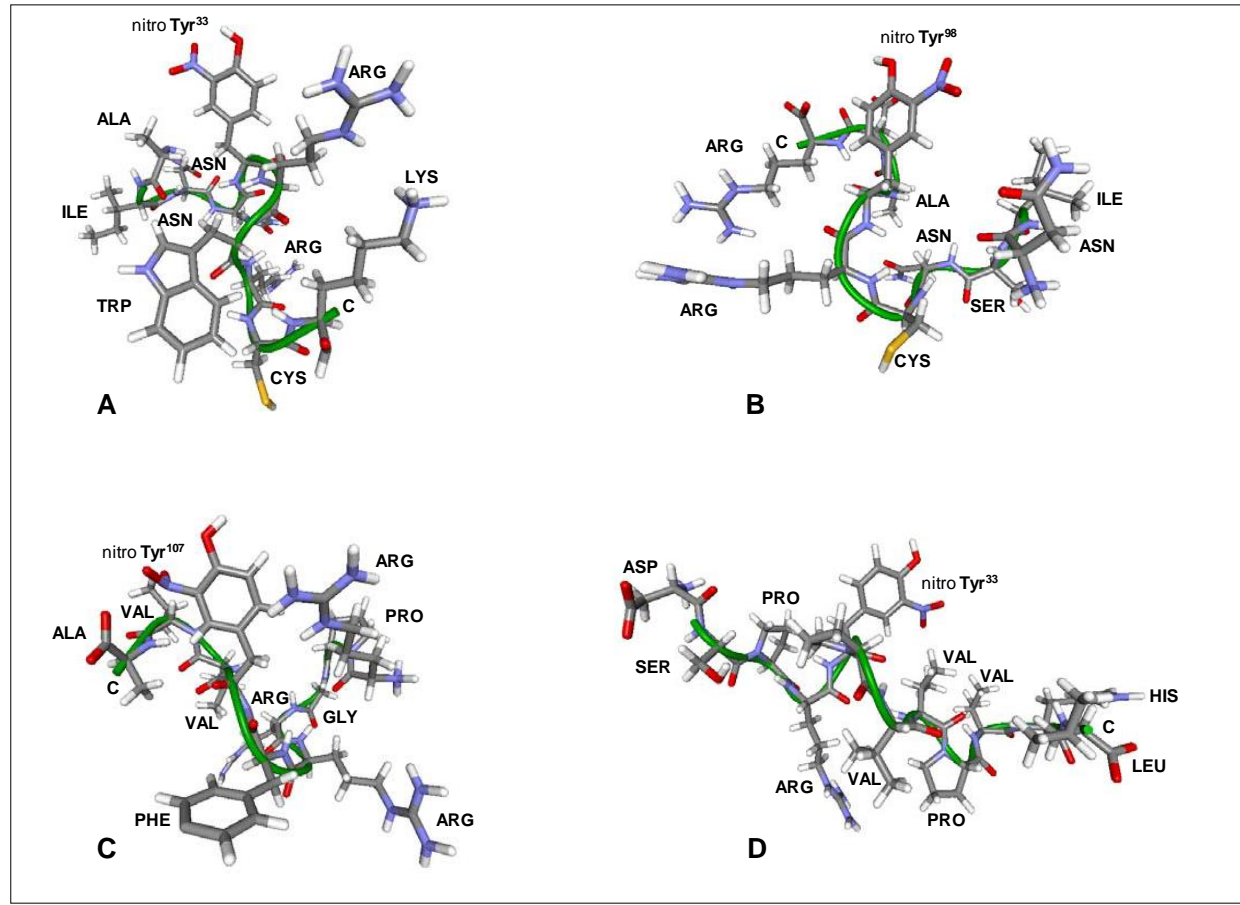

Fig 5. Structural modeling of nitrated model peptides. $\mathrm{ECP}_{1}(\mathrm{~A}), \mathrm{ECP}_{2}(\mathrm{~B}), \mathrm{ECP}_{3}(\mathrm{C}), \mathrm{ECP}_{4}(\mathrm{D})$.

\section{Conclusions}

In green is represented the no regular random coil secondary peptide's structures

In the present study, we have synthesized and structural characterized the synthetic ECP nitrated peptide. The major goal was to characterize the affinity and binding affinity of a monoclonal 3-NT-antibody to these tyrosine nitrated peptide and to identity the major factor which determine the selectivity of the in vivo eosinophil nitration.

An indirect ELSA method was developed in order to investigate the binding affinity of nitrated ECP peptides to the monoclonal antibody in which the results showed that the 3-nitrotyrosine antibody recognizes a specific sequence motif comprising several amino acids in the proximity of nitroTyr ${ }^{33}$ residue (Fig.1). In addition to the characterization of sequence variations, conformational studies and computational molecular modeling of ECP protein and synthetic nitrated ECP peptides were performed. The CD data indicate that the $\mathrm{Tyr}^{33}$ (from $\mathrm{ECP}_{1}$ peptide sequences) is placed on the surface of eosinophil proteins, having a flexible, random coil structure. Such data suggest that surface expositions of tyrosine-nitrated sites are important factor in in vivo tyrosine nitration.

Using solvent accessible surface area (SASA) computational analysis of all tyrosine residues in ECP we observed that $\mathrm{Tyr}^{33}$ showed the largest SASA being the most exposed tyrosine to the protein surface. Moreover calculating the 
radial distribution functions (RDF) of the oxygen atom of water molecules around the hydroxyl oxygen atom of each of the four tyrosine residues we observed that the same in vivo nitrated $\mathrm{Tyr}^{33}$ residue has the most numerous interactions with the solvent, slightly higher than $\mathrm{Tyr}^{122}$, and more numerous than $\mathrm{Tyr}^{107}$ and $\mathrm{Tyr}^{98}$ which is buried in the ECP protein structure.

Based on these data the specifies of anti 3-NT antibody to nitro-tyrosine peptides can be of interest in further studies to generate antibodies for specific motif containing tyrosine residue and why not for development of a potential specific biomarkers for in vivo protein nitration.

Acknowledgments: This work was supported by the Romanian National Authority for Scientific Research CNCS-UEFISCDI, Project number PN-II-RU-TE-2014-4-0920. Funding by the Ministry of Research and Innovation within Program 1 - Development of the national RD system, Subprogram 1.2 - Institutional Performance - RDI excellence funding projects, Contract no. 34PFE/19.10.2018 is gratefully acknowledged by Dr. Brindusa-Alina Petre.

\section{References}

1.ROSENBERG, H.F., DYER, K.D., FOSTER, P.S., Nat. Rev. Immunol., 13, 2013, p. 9.

2.MUNTHE-KAAS, M.C., GERRITSEN, J., CARLSEN, K.H., UNDLIEN, D., EGELAND, T., SKINNINGSRUD, B., TØRRES, T., CARLSEN, K.L., Allergy, 62, 2007, p. 429.

3.DUGUET, A., IIJIMA, H., EUM, S.Y., HAMID, Q., EIDELMAN, D.H., Am. J. Respir. Crit. Care Med., 164, 2001, p.1119.

4.RAVI ACHARYA, K., ACKERMAN, S. J., J. Biol. Chem., 289, no. 25, 2014, p.17406.

5.GLEICH, G.J., OTTESEN, E.A., LEIFERMAN, K.M., ACKERMAN, S.J., Int. Arch. Allergy. Appl. Immunol., 88, p.198959.

6.PETERSON, C.G., JÖRNVALL, H., VENGE, P., Eur. J. Haematol., 40, 1988, p. 415.

7.KRÜCKEL, A., MOREIRA, A., FRÖHLICH, W., SCHULER, G., HEINZERLING, L., B.M.C. Cancer., 19, no. 1, 2019 , p. 207.

8.VENGE, P., BYSTRÖM, J., CARLSON, M., HÂKANSSON, L., KARAWACJZYK, M., PETERSON, C., SEVÉUS, L., TRULSON, A., Clin. Exp. Allergy., 29, no. 9, 1999, p. 1172.

9.THOMSON, L., Dis. Markers., 201, 2015, p. 708282.

10.CERIELLO, A., MERCURI, F., QUAGLIARO, L., ASSALONI, R., MOTZ, E., TABOGA, C., Diabetolog., 44, no.7, 2001 , p.834.

11.SACKSTEDER, C.A., QIAN, W.J., KNYUSHKO, T.V., WANG, H., CHIN, M.H., LACAN, G., MELEGA, W.P., CAMP, D.G ${ }^{2 n d}$., SMITH, R.D., SQUIER, T.C., BIGELOW, D.J., Biochem.,45, no.26, 2006, p.8009.

12.BANCILA, S., PINTILIE, O., GRADINARU, R., SANDU, I., DROCHIOIU, G., BALAN, G., REV.CHIM. (Bucharest), 67, no. 5, 2016, p. 974.

13.DROCHIOIU, G., MURARIU, M., PETRE, B-A., MANEA, M., PRZYBYLSKI, M., REV.CHIM. (Bucharest), 58, no. 3, 2007 , p. 311.

14.BEASLEY, A.S., ANDERSON, C., MCARTHUR, J. et al. Clin. Proteom., 6, 2010, p. 29.

15.GUNAYDIN, H., HOUK, K. N., Chem. Res. Toxicol., 22, no.5, 2009, p.894.

16.Van DALEN, C. J., WINTERBOURN, C., KETTLE, A.J., Biochem. J., 394, no. 3, 2006, p.707.

17.DUNCAN, M. W., Amino Acids, 25, no. 3-4, 2003, p. 351.

18.REIMERT, C.M., VENGE, P., KHARAZMI, A., BENDTZEN, K., J. Immunol. Method., 138, 1991, p. 285.

19.BOIX, E., CARRERAS, E., NIKOLOVSKI, Z., CUCHILLO, C.M., NOGUÉS, V.M., J. Leukocyte Biology, 69, 2001 , p.1027.

20.FRANZE, T., WELLER, M.G., NIESSNER, R., POSCHL, U., Analyst, 129, 2004, p. 589.

21.PETRE, B.A., YOUHNOVSKI, N., LUKKARI, J., WEBER, R., PRZYBYLSKI, M., Eur. J. Mass Spectrom. 11, 2005 , p. 513.

22.ULRICH, M., PETRE, A., YOUHNOVSKI, N., WORLITZSCH, D., PRZYBYLSKI, M, DÖRING, G., J. Biol. Chem., 283, 2008, p. 28629.

23.ABELlO, N., KERSTJENS, H.A., POSTMA, D.S., BISCHOFF, R., J. Proteome Res. 8, 2009, p. 3222.

24.SARVER, A., SCHEFFLER, N.K., SHETLAR, M.D., GIBSON, B.W., J. Am. Soc. Mass. Spectrom., 12, no.4, 2001 , p.439.

25.DRAGUSANU, M., PETRE, B.A., PRZYBYLSKI, M., J. Peptide Sci., 17, 2011, p. 184.

26.DANQUAH, B.D., YEFREMOVA, Y., OPUNI, K.F.M., RÖWER, C., KOY, C., GLOCKER, M.O., J. Proteomics., 1, 2019 , p. 103572.

27.ION, L., PETRE, B.A., Adv. Exp. Med. Biol., 1140, 2019, p. 377.

28.DIACONESCU, B. M., JITARU, D., DRAGOS, M.L., BADESCU, M., STEFANACHE, T., CIOCOIU, M., MOCANU, M., BADESCU, C., REV.CHIM. (Bucharest), 69, no. 3, 2018, p. 597.

29.MIHALCEANU, M., DIMITRIU, D.C., LAZAR, I.T., PETRE, B-A., CONSTANTINESCU, G., NEMESCU, G., SCRIPCARIU, I., REV.CHIM.(Bucharest), 69, no. 6, 2018, p. 1509.

30.WALLACE, B.A., Curr. Opin. Struct. Biol., 58, 2019, p. 191.

31.KUMAGAI, P.S., ARAUJO, A.P., LOPES, J.L., Biophys. Rev., 9, no. 5, 2017, p. 517.

32.SHAH, K., MAGHSOUDLOU, P., Br. J. Hosp. Med., 77, no. 7, 2016, p. 98.

33.AYDIN, S., Peptides, 72, 2015, p. 4.

34.MOHAN, C.G., BOIX, E., EVANS, H.R., NIKOLOVSKI, Z., NOGUES, M.V., CUCHILlO, C.M., ACHARYA, K.R., Biochem., 41, 2002, p. 12100.

35.EISENHABER, F., LIJNZAAD, P., ARGOS, P., SANDER, C., SCHARF, M., J. Comput. Chem., 16, 1995, p. 273.

36.ABRAHAM, M J, et al., SoftwareX, 1, no. 2, 2015, p. 19.

37.BOWERS, K. J., CHOW, E., XU, H., DROR, R.O., et al., Proceedings of the ACM/IEEE Conference on Supercomputing (SC06), Tampa, Florida, 2006, November 11-17.

38.SCHRÖDINGER Release 2019-3: Desmond Molecular Dynamics System, SHAW, D. E. Research, New York, NY, 2019. Maestro-Desmond Interoperability Tools, Schrödinger, New York, NY, 2019.

39.ROBERTSON, M. J., et al. J. Chem. Theory Comput., 11, no.7, 2015, p. 3499.

40.JORGENSEN, W. L.; CHANDRASEKHAR, J.; MADURA, J. D.; IMPEY, R. W.; KLEIN, M. L., J. Chem. Phys, 79, 1983 , p. 926.

41.DARDEN, T., YORK, D., PEDERSEN, L., J. Chem. Phys., 98, no.12, 1993, p.10089.

42.SHIRTS, M. R., et al. J. Comput. Aided Mol. Des., 31, no.1, 2017, p. 147.

43.SØNDERGÅRD-ANDERSEN. J., LAURITZEN. E., LIND. K., HOLM. A., J. Immunol. Methods, 131, no.1, 1990 , p. 99.

Manuscript received: 10.12 .2019 
